Abstract G112 Table 2 Association between chorioamnionitis and MRI measures

\begin{tabular}{|c|c|c|c|c|c|}
\hline & \multicolumn{3}{|c|}{ Chorioamnionitis } & \multicolumn{2}{|c|}{ Coefficient $(95 \% \mathrm{Cl})$ Adjusted p value ${ }^{\alpha}$} \\
\hline & $\begin{array}{l}\text { None } \\
(n=165)\end{array}$ & $\begin{array}{c}\text { Maternal response } \\
\text { only } \\
(n=15)\end{array}$ & $\begin{array}{l}\text { Both maternal and } \\
\text { fetal response } \\
(n=32)\end{array}$ & $\begin{array}{l}\text { Maternal response compared with } \\
\text { none }\end{array}$ & $\begin{array}{l}\text { Both maternal \& fetal response } \\
\text { compared with none }\end{array}$ \\
\hline \multicolumn{6}{|l|}{ Brain measures } \\
\hline $\begin{array}{l}\text { Brain biparietal diameter } \\
(\mathrm{mm})\end{array}$ & $82.5(4.5)$ & $84.0(3.8)$ & $83.1(4.2)$ & $\begin{array}{c}2.0(-0.1,3.9) \\
p=0.05\end{array}$ & $\begin{array}{c}1.6(-0.1,3.2) \\
p=0.06\end{array}$ \\
\hline $\begin{array}{l}\text { Corpus callosum - genu } \\
(\mathrm{mm})\end{array}$ & $4.3(1.4)$ & $3.6(1.6)$ & $4.1(1.4)$ & $\begin{array}{c}-0.2(-0.8,0.3) \\
p=0.42\end{array}$ & $\begin{array}{c}0.3(-0.1,0.8) \\
p=0.14\end{array}$ \\
\hline $\begin{array}{l}\text { Corpus callosum - body } \\
\text { (mm) }\end{array}$ & $2.1(0.5)$ & $2.0(0.6)$ & $2.0(0.6)$ & $\begin{array}{c}0.02(-0.2,0.3) \\
p=0.88\end{array}$ & $\begin{array}{c}0.08(-0.1,0.3) \\
p=0.48\end{array}$ \\
\hline $\begin{array}{l}\text { Corpus callosum - } \\
\text { splenium (mm) }\end{array}$ & $3.8(1.0)$ & $3.5(1.6)$ & $3.4(1.0)$ & $\begin{array}{c}-0.03(-0.7,0.6) \\
p=0.92\end{array}$ & $\begin{array}{c}-0.05(-0.4,0.3) \\
p=0.79\end{array}$ \\
\hline $\begin{array}{l}\text { Deep nuclear gray matter } \\
\left(\mathrm{mm}^{2}\right)\end{array}$ & $1235.6(106.2)$ & $1262.9(102.5)$ & $1244.6(105.9)$ & $\begin{array}{c}23.5(-28.5,75.6) \\
p=0.38\end{array}$ & $\begin{array}{c}13.2(-28.9,55.3) \\
p=0.54\end{array}$ \\
\hline $\begin{array}{l}\text { Transcerebellar diameter } \\
(\mathrm{mm})\end{array}$ & $55.5(3.1)$ & $54.8(2.8)$ & $55.2(3.0)$ & $\begin{array}{c}-0.4(-1.7,1.0) \\
p=0.58\end{array}$ & $\begin{array}{c}0.6(-0.4,1.5) \\
p=0.22\end{array}$ \\
\hline \multicolumn{6}{|l|}{ CSF measures } \\
\hline $\begin{array}{l}\text { Right lateral ventricle } \\
\text { (mm) }\end{array}$ & $5.9(1.8)$ & $6.7(3.5)$ & $6.2(1.9)$ & $\begin{array}{c}0.7(-1.0,2.3) \\
p=0.45\end{array}$ & $\begin{array}{c}0.2(-0.5,0.8) \\
p=0.63\end{array}$ \\
\hline Left lateral ventricle ( $\mathrm{mm}$ ) & $5.6(1.8)$ & $6.1(3.1)$ & $5.8(2.0)$ & $\begin{array}{c}0.3(-1.1,1.8) \\
p=0.64\end{array}$ & $\begin{array}{c}-0.1(-0.8,0.6) \\
p=0.77\end{array}$ \\
\hline $\begin{array}{l}\text { Interhemispheric distance } \\
\text { (mm) }\end{array}$ & $2.8(1.3)$ & $2.9(1.7)$ & $3.2(1.9)$ & $\begin{array}{c}-0.1(-0.9,0.8) \\
p=0.83\end{array}$ & $\begin{array}{c}0.03(-0.7,0.7) \\
p=0.93\end{array}$ \\
\hline \multicolumn{6}{|l|}{ Brain maturation } \\
\hline $\begin{array}{l}\text { PLIC myelination } \\
\text { complete, } \mathrm{n}(\%)\end{array}$ & $139(84.2)$ & $14(93.3)$ & $27(84.4)$ & $\begin{array}{c}2.0(0.2,23.6)^{\bullet} \\
\quad p=0.59\end{array}$ & $\begin{array}{c}0.9(0.3,2.6)^{*} \\
p=0.89\end{array}$ \\
\hline $\begin{array}{l}\text { Gyral maturation }>38 \\
\text { weeks, } \mathrm{n}(\%)\end{array}$ & $94(57.0)$ & $5(33.3)$ & $13(40.6)$ & $\begin{array}{c}0.4(0.2,1.3)^{*} \\
p=0.13\end{array}$ & $\begin{array}{c}1.0(0.4,2.4)^{*} \\
p=0.92\end{array}$ \\
\hline
\end{tabular}

* Results presented as odds ratios $(95 \% \mathrm{Cl})$

\& Using GEE with robust standard errors to account for multiple births, all analyses adjusted for gestation at MRI, gestation at birth, sex and bw sds

collected and chorioamnionitis, characterised into either no inflammatory response, maternal response only or both fetal and maternal response. All infants had brain MRI scans at term equivalent age. T1 and T2 weighted images were systematically scored for size of cerebral structures, degree of myelination, gyral maturation, signal abnormalities and presence of cysts. Differences between groups were compared using linear regression for continuous variables and logistic regression for categorical variables.

Results Of the 237 infants included in this study, 58 (24.5\%) had histological evidence of chorioamnionitis.

Table 1 summarises the demographic data. Infants with evidence of chorioamnionitis on placental histology had higher rates of preterm delivery $(\mathrm{p}<0.0001)$, low birth weight $(\mathrm{p}=$ $0.04)$ and prolonged rupture of membranes $(p<0.0001)$. Those with chorioamnionitis had higher rates of intraventricular haemorrhage ( $\mathrm{p}<0.0001)$.

Chorioamnionitis, however, was not associated with brain injury or delayed maturation on qualitative MRI assessment. The MRI scoring data is shown in Table 2.

\section{G113(P) SURVIVAL IN INFANTS BORN AT LESS THAN 24 WEEKS GESTATION - A POPULATION BASED STUDY}

${ }^{1} S$ Tiwary, ${ }^{2} \mathrm{R}$ Geethanath, ${ }^{3} \mathrm{~B}$ Reichert, ${ }^{3} \mathrm{~S}$ Janakiraman, ${ }^{4} \mathrm{~S}$ Garg, ${ }^{1} \mathrm{~N}$ Embleton. ${ }^{1}$ Newcastle Neonatal Service, Newcastle Hospitals NHS Foundation Trusts, Newcastle-Upon-Tyne, UK; ${ }^{2}$ Neonatal Unit, Sunderland Royal Infirmary, Sunderland, UK; ${ }^{3}$ Neonatal Unit, University Hospital of North Tees, Stockton-Upon-Tees, UK; ${ }^{4}$ Neonatal Unit, James Cook University Hospital, Middlesborough, UK

\subsection{6/archdischild-2015-308599.112}

Background The management of infants born at less than 24 weeks gestation $(<24 \mathrm{w})$ remains contentious. In a large population based cohort 1993-2008 we previously showed no appreciable increase in long-term survival for liveborn infants $<24 \mathrm{w}$, although median age at death increased over each successive 5 -year epochs. We aimed to review recent changes in survival $<24 \mathrm{w}$, and to determine risk factors that might predict non-survival at an earlier age.

Methods Cases (live-born infants at 22-23w) were identified using a well-validated population based database (Regional Maternity Survey Office, Northern Region, UK) for the 5-year epoch 2008-2012. We included cases still alive at $6 \mathrm{~h}$ of age, in order to identify a group where the intention to provide active management appears likely. Survivors were identified from unit databases of the 4 tertiary level neonatal units, and individual case notes reviewed.

Results During the study period 55 infants $(56 \%$ male) born at $22-23 \mathrm{w}$ ( $\mathrm{n}=2$ at $22 \mathrm{w}$ ) were alive at $6 \mathrm{~h}$ (birth prevalence $\sim 4: 10,000)$. Of these $24 / 55$ infants $(44 \%)$ were alive at 12 months age $(50 \%$ male); $18 / 24$ survivors received at least one dose of steroids. Median survival of non-survivors was 2.65 days (excludes one case known to have died at $>2$ years age). $7 / 31$ non-survivors had a laparotomy, 3 had retinopathy of prematurity (ROP) treatment, 3 had PDA ligation, and only 2/31 ever achieved full feeds. Amongst survivors, 20/24 required some form of invasive surgery/intervention (4 laparotomy, 2 other surgery, 15 laser ROP, 2 Avastin for ROP, and 14 PDA ligation.) There was no significant difference in birthweight between survivors and non-survivors. Initial analysis did not identify early postnatal factors that enabled clear identification of infants who subsequently died.

Conclusion Survival at $<24 \mathrm{w}$ has increased dramatically in this population over the last few years, but was not associated with a prolonged period of intensive care in those who did not survive. However, there was considerable morbidity (e.g. surgical procedures) in both groups. Increased survival may be due to several factors, and will be affected by clinician and parental attitudes. 